\section{An Enantioselective Synthetic Route to cis-2,4- Disubstituted and 2,4-Bridged Piperidines}

\author{
Mercedes Amat, ${ }^{*}$ Maria Pérez, Annamaria T. Minaglia, and \\ Joan Bosch" \\ Laboratory of Organic Chemistry, Faculty of Pharmacy, and \\ Institute of Biomedicine (IBUB), University of Barcelona, \\ 08028-Barcelona, Spain \\ amat@ub.edu,joanbosch@ub.edu
}

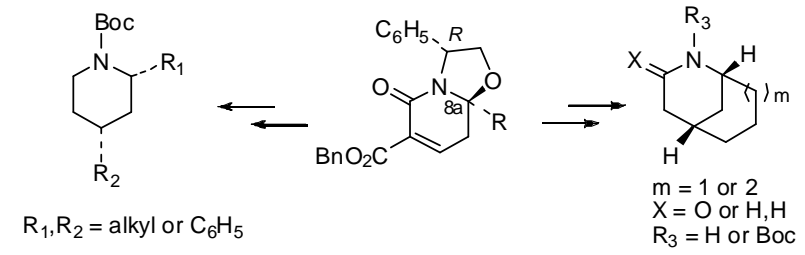

A synthetic route to enantiopure cis-2,4-disubstituted and 2,4-bridged piperidines is reported, the key step being a stereoselective conjugate addition of an organocuprate to a phenylglycinol-derived unsaturated lactam bearing a substituent at the 8a-position.

\footnotetext{
Aminoalcohol-derived oxazolopiperidone lactams are exceptionally versatile building blocks for the enantioselective construction of structurally diverse piperidine-containing natural products and bioactive compounds. ${ }^{1}$ These lactams allow the substituents to be introduced at the different ring positions in a regio- and stereocontrolled manner, providing easy access to enantiopure polysubstituted piperidines bearing virtually any type of substitution pattern. ${ }^{2}$ In particular, the conjugate addition to $\alpha, \beta$-unsaturated oxazolopiperidone lactams allows the stereocontrolled formation of a $\mathrm{C}-\mathrm{C}$ bond at the piperidine 4-position, and has successfully been used to generate either cis or trans 3,4-disubstituted enantiopure piperidine-containing derivatives, including the antidepressant drug (-)-paroxetine, ${ }^{3}$ cis-fused perhydrocycloalka[c]pyridines ${ }^{4}$ and the indole alkaloid (+)-uleine. ${ }^{5}$

To further expand the potential of these lactams we decided to explore a synthetic route to enantiopure 2,4-bridged piperidine derivatives, as outlined in Scheme 1. The key step would be the stereocontrolled introduction of an appropriate unsaturated chain at the 4-position of the piperidine ring by conjugated addition of an organocuprate to an unsaturated lactam A bearing an unsaturated substituent at the 2-position. A subsequent ring-closing metathesis from the resulting cis-
}

2,4-disubstituted piperidine derivative would lead to the target bridged azabicyclo.

\section{SCHEME 1. Synthetic Strategy}

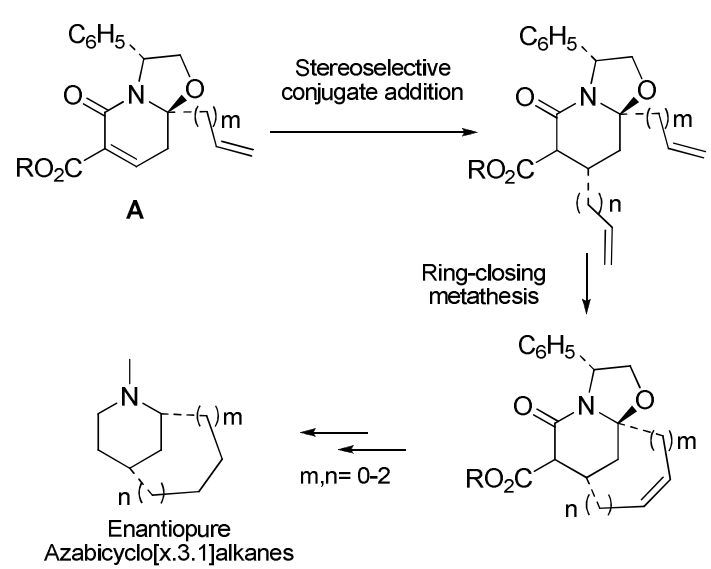

It has previously been established ${ }^{6}$ that the conjugate addition of organocuprates to unsaturated oxazolopiperidone lactams $\mathbf{B}$ (when $\mathrm{R}=\mathrm{H}$ ) is highly stereoselective as a consequence of the conformational rigidity of the bicyclic system. The nucleophilic attack occurs under stereoelectronic control $^{7}$ on the exo face, axial to the electrophilic carbon of the conjugate double bond (Figure 1). ${ }^{8}$ However, it could be expected $^{9}$ a priori that the presence of a substituent at the angular position $(\mathrm{R} \neq \mathrm{H})$ could alter the stereochemical outcome of the conjugate addition as a consequence of the 1,3-syn diaxial interactions between this substituent and the incoming nucleophile. For this reason, to evaluate the viability of our synthetic plan we decided to carry out a preliminary study on the stereoselectivity of similar conjugate addition reactions from the model, more easily accessible, unsaturated lactams 3a and 3b. These lactams were prepared, ${ }^{10}$ via the corresponding selenides 2 (diastereomeric mixtures), from the known lactams $\mathbf{1 a}$ and $\mathbf{1} \mathbf{b}^{11}$ (Scheme 2). The easily removable benzyloxy-carbonyl electron-withdrawing group was used to enhance the reactivity of the conjugated system. ${ }^{12}$

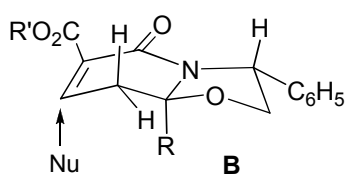

FIGURE 1. Stereoelectronic control in the conjugate addition.

The conjugate addition of a vinyl group to lactam 3a was satisfactorily accomplished (62\% overall yield from $2 \mathrm{a})$ with vinylmagnesium bromide in the presence of $\mathrm{LiCl}, \mathrm{CuI}$, and trimethylsilyl chloride ${ }^{13}$ in THF. The high exo facial stereoselectivity of the conjugate addition was confirmed after removal of the benzyloxycarbonyl substituent present in $\mathbf{4 a}$ by hydrogenolysis, which took place with simultaneous hydrogenation of the vinyl group, followed by thermal decarboxylation. Under these conditions a 93:7 mixture 
(calculated by NMR) of lactam 7a and its C-7 epimer was obtained (see Table 1).

SCHEME 2. Conjugate Addition to 8a-Substituted Unsaturated Oxazolopiperidone Lactams

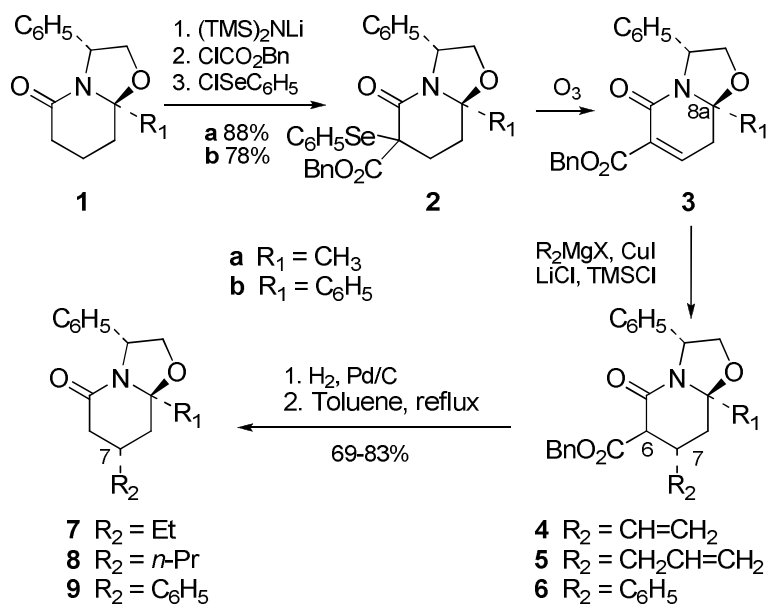

Under the same conditions the sterically more demanding 8a-phenyl substituted lactam $\mathbf{3 b}$ gave a similar result: the conjugate addition of a vinyl residue took place in $61 \%$ yield (from 2b) and the subsequent debenzyloxycarbonylation afforded (73\%) a 94:6 diastereomeric mixture of $7 \mathbf{b}$ and its C7 epimer.

Similar conjugate additions of allylmagnesium chloride to unsaturated lactams $\mathbf{3 a}$ and $\mathbf{3 b}$ took place with lower stereoselectivity and, after removal of the benzyloxycarbonyl group as in the above series, lactams $\mathbf{8 a}$ and $\mathbf{8 b}$ were obtained along with the corresponding C-7 epimers (78:22 and 85:15 ratio, respectively) in acceptable overall yield (50\% from $\mathbf{2 a}$; $65 \%$ from $2 b$ ).

A moderate stereoselectivity was also observed in the conjugate addition of the organocuprate derived from phenylmagnesium chloride to $\mathbf{3 a}$ : a $84: 16$ mixture of lactam 9a and its C-7 epimer was isolated in 51\% overall yield from 2a.

In contrast, somewhat surprisingly, the conjugate addition of this organocuprate to the 8a-phenyl substituted lactam $\mathbf{3 b}$ took place in excellent yield and very high exo stereoselectivity (Table 1), ultimately leading to lactam $\mathbf{9 b}$ in $60 \%$ overall yield (from $2 \mathrm{~b}$ ). A $\pi$-stacking interaction between the incoming- and 8a-phenyl groups could account for the high stereoselectivity.

TABLE 1. Conjugate Addition Reactions from Unsaturated Lactams 3

\begin{tabular}{cccc}
$\begin{array}{c}\text { unsaturated } \\
\text { lactam }\end{array}$ & product & $\begin{array}{c}\text { yield } \\
(\%)^{a}\end{array}$ & $\begin{array}{c}\mathrm{R}_{1} / \mathrm{R}_{2} \text { cis:trans } \\
\text { ratio }^{b}\end{array}$ \\
\hline 3a & $\mathbf{4 a}$ & 62 & $93: 7$ \\
3a & $\mathbf{5 a}$ & 70 & $78: 22$ \\
3a & 6a & 74 & $85: 16$ \\
3b & 4b & 61 & $94: 6$
\end{tabular}

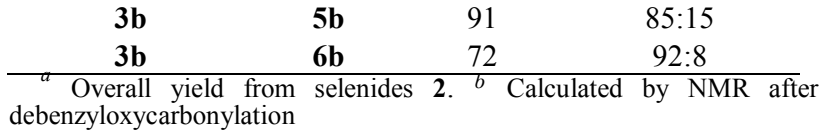

To illustrate the synthetic usefulness of the above methodology, the phenyl-substituted lactams 9a and 9b were converted to enantiopure cis-2,4-disubstituted piperidines as shown in Scheme 3. Thus, treatment of lactams 9 with $\mathrm{LiAlH}_{4}$ brought about both the reduction of the amide carbonyl group and the reductive opening of the oxazolidine ring, which took place with complete retention of configuration, ${ }^{14}$ to give piperidines 10a and 10b. The cis-relationship of the piperidine substituents at C-2 and C-4 in $\mathbf{1 0}$ was evident from the multiplicity of the axial 2 and 4 protons in the NMR spectra (see Supporting Information), thus confirming the stereochemical outcome of the above conjugate additions. A subsequent debenzylation in the presence of $(\mathrm{Boc})_{2} \mathrm{O}$ gave enantiopure piperidines 11a and $\mathbf{1 1 b}$.

\section{SCHEME 3. Synthesis of Enantiopure cis-2,4-Disubstituted Piperidines}

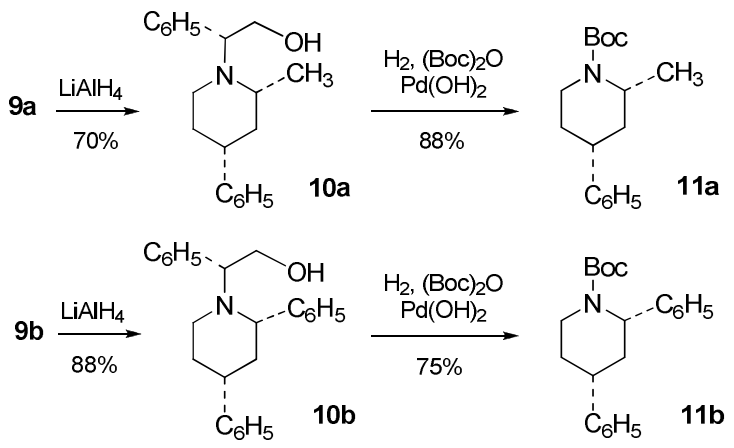

The above results made evident that the presence of a substituent at the angular 8a-position has little effect on the stereoselectivity of the conjugate addition. However, to access bridged piperidine derivatives following the strategy outlined in Scheme 1, we decided to take advantage of the higher stereoselectivity of the vinyl conjugate additions and chose starting lactams A bearing an allyl or 3-butenyl substituent at the 8a-position, which should ultimately lead to 6,6 and 6,7 bridged azabicyclic systems, respectively.

The synthetic sequence is outlined in Scheme 4. The required unsaturated lactams $14^{10}$ were prepared from lactams $\mathbf{1 2} \mathbf{a}^{15}$ and $\mathbf{1 2} \mathbf{b}^{16}$ via the corresponding selenides 13. As could be expected from the above model experiments, the conjugate addition of the organocuprate derived from vinylmagnesium bromide to crude lactams 14 took place in good yield $(\sim 60 \%$ from 13) and excellent facial diastereoselectivity to give the exo compounds $\mathbf{1 5}$ as C-6 epimeric mixtures (only trace amounts of C-7 endo epimers were detected by NMR), which were directly cyclized ( $\sim 80 \%$ yield $)$ in the presence of the second generation Grubbs catalyst. ${ }^{17}$ A subsequent catalytic hydrogenation of the resulting bridged derivatives $\mathbf{1 6}$ brought about both the reduction of the $\mathrm{C}-\mathrm{C}$ double bond and debenzylation to lead, after thermal decarboxylation, to 
tricyclic lactams $17 \mathbf{a}(78 \%)$ and $\mathbf{1 7 b}(83 \%)$. In the 6,7 bridged series, lactam 17b was converted to the enantiopure 7azabicyclo[4.3.1]decane (B-homomorphan) 19b (58\% overall yield) by alane reduction followed by hydrogenolysis in presence of $(\mathrm{Boc})_{2} \mathrm{O} .{ }^{18}$ However, in 17a the reductive cleavage of the $\mathrm{C}-\mathrm{O}$ bond of the oxazolidine ring was more difficult, probably because the process involves the bridgehead carbon of a 6,6 bridged system. In this series, alane reduction of $\mathbf{1 7 a}$ caused only the reduction of the lactam carbonyl. A subsequent prolonged $(48 \mathrm{~h})$ treatment of the resulting tricyclic amine with $\mathrm{Et}_{3} \mathrm{SiH}-\mathrm{TiCl}_{4}$ led to bicyclic amine 18a (48\% overall yield from 17a), which was then converted to the enantiopure 2-azabicyclo[3.3.1]nonane (morphan) 19a as in the above 6,7 bridged series. ${ }^{19}$ Alternatively, in the Bhomomorphan series, tricyclic lactam $\mathbf{1 7 b}$ was converted to lactam 21 in two steps (65\% overall yield) as depicted in Scheme 4.

SCHEME 4. Synthesis of Enantiopure 2-

Azabicyclo[3.3.1]nonanes and 7-Azabicyclo[4.3.1]decanes

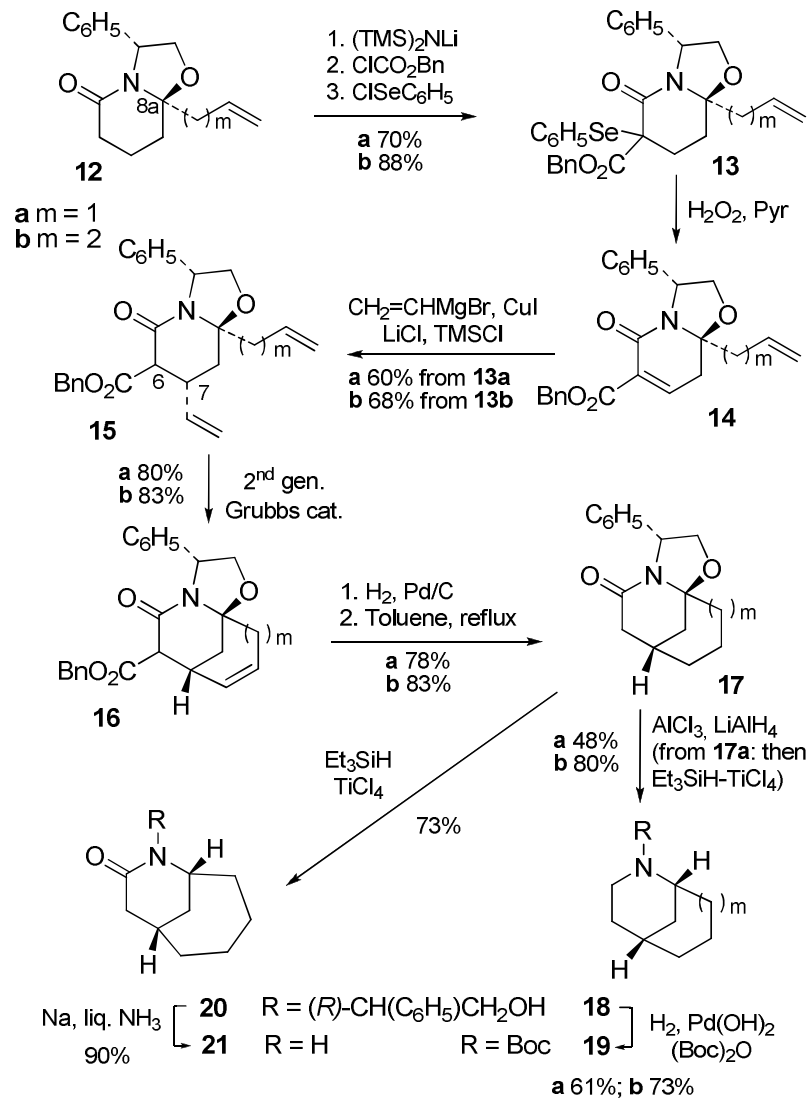

In summary, the exo facial stereoselectivity observed in the conjugate addition of organocuprates to 8a-unsubstituted unsaturated oxazolopiperidone lactams $\mathbf{B}(\mathrm{R}=\mathrm{H})$ is maintained in the 8a-substituted derivatives, in particular when the incoming group is vinyl. By choosing the appropriate substituent at the $8 \mathrm{a}$ position in the starting oxazolopiperidone and the appropriate organocuprate in the conjugate addition step, the reported methodology provides a versatile route to enantiopure cis-2,4-disubstituted and 2,4bridged piperidines. ${ }^{20}$

\section{Experimental Section}

General Procedure for the Conjugate Addition to Unsaturated Lactams (with $4 \mathrm{a}$ as an example). $\mathrm{LiCl}$ (189 $\mathrm{mg}, 4.5 \mathrm{mmol})$ was heated at $80^{\circ} \mathrm{C}$ for $1 \mathrm{~h}$ under vacuum $(10-$ $15 \mathrm{~mm} \mathrm{Hg}$ ) in a three-necked, $500 \mathrm{~mL}$ round-bottomed flask. Then, $\mathrm{CuI}(357 \mathrm{mg}, 4.5 \mathrm{mmol})$ and THF $(5 \mathrm{~mL})$ were added at $\mathrm{rt}$, and the mixture was stirred at $\mathrm{rt}$ for $5 \mathrm{~min}$. The suspension was cooled at $-78{ }^{\circ} \mathrm{C}$, and vinylmagnesium bromide $(1 \mathrm{M}$ in THF, $4.5 \mathrm{~mL})$, TMSCl $(0.57 \mathrm{~mL}, 4.5 \mathrm{mmol})$, and the crude of unsaturated lactam 3a $(1.8 \mathrm{mmol})$ in THF $(8 \mathrm{~mL})$ were successively added. The resulting mixture was stirred at -78 ${ }^{\circ} \mathrm{C}$ for $20 \mathrm{~h}$. The reaction was quenched with saturated aqueous $\mathrm{NH}_{4} \mathrm{Cl}$, and the organic layer was extracted with EtOAc. The combined organic extracts were dried and concentrated. Flash chromatography (1:4 EtOAc-hexane) gave lactams 4a (major) and 7-epi-4a as mixtures of C-6 epimers (508 mg, 62\% overall yield from 2a). 4a (major C-6 epimer): IR (NaCl) 1665, $1744 \mathrm{~cm}^{-1} ;{ }^{1} \mathrm{H}$ NMR (400 MHz, $\mathrm{CDCl}_{3}$, COSY, HETCOR) $\delta 1.54\left(\mathrm{~s}, 3 \mathrm{H}, \mathrm{CH}_{3}\right), 1.94(\mathrm{dd}, J=14.4,8.4$ $\mathrm{Hz}, 1 \mathrm{H}, \mathrm{H}-8), 2.38$ (dd, $J=14.4,7.2 \mathrm{~Hz}, 1 \mathrm{H}, \mathrm{H}-8), 3.15$ (m, $1 \mathrm{H}, \mathrm{H}-7), 3.40$ (d, $J=10.8 \mathrm{~Hz}, 1 \mathrm{H}, \mathrm{H}-6), 4.03$ (dd, $J=9.2$, $6.8 \mathrm{~Hz}, 1 \mathrm{H}, \mathrm{H}-2), 4.41$ (t, $J=8.4 \mathrm{~Hz}, 1 \mathrm{H}, \mathrm{H}-2), 5.09$ (m, 2H, $\left.\mathrm{CH}_{2}=\right), 5.17\left(\mathrm{~d}, J=12.4 \mathrm{~Hz}, 1 \mathrm{H}, \mathrm{CH}_{2}\right.$ benzyl), 5.24 (d, $J=$ $12.4 \mathrm{~Hz}, 1 \mathrm{H}, \mathrm{CH}_{2}$ benzyl), 5.42 (t, $\left.J=7.2 \mathrm{~Hz}, 1 \mathrm{H}, \mathrm{H}-3\right), 5.74$ (ddd, $J=17.2,10.4,7.2 \mathrm{~Hz}, 1 \mathrm{H}, \mathrm{CH}=), 7.25-7.36(\mathrm{~m}, 10 \mathrm{H}$ $\mathrm{ArH}) ;{ }^{13} \mathrm{C}$ NMR $\left(100.6 \mathrm{MHz}, \mathrm{CDCl}_{3}\right) \delta 26.7\left(\mathrm{CH}_{3}\right), 36.0(\mathrm{C}-$ 7), 39.5 (C-8), 53.7 (C-6), 59.1 (C-3), 67.0 ( $\mathrm{CH}_{2}$ benzyl), 69.2 (C-2), 93.2 (C-8a), $116.5\left(\mathrm{CH}_{2}=\right), 124.5-128.5$ (C-o, $\left.m, p\right)$, 135.6, 139.7 (C-i), $138.1(\mathrm{CH}=), 166.7$ (NCO), 168.7 (COO). Anal. Calcd for $\mathrm{C}_{24} \mathrm{H}_{25} \mathrm{NO}_{4}$ : C, 73.64; H, 6.44; N, 3.58. Found: C, 73.30; H, 6.58; N, 3.51.

General Procedure for the Ring-closing Metathesis Reaction (with 16a as an example). Second-generation Grubbs catalyst ( $3 \mathrm{mg}$ ) was added to a solution of lactams 15a (20 mg, $0.05 \mathrm{mmol})$ in $\mathrm{CH}_{2} \mathrm{Cl}_{2}(7 \mathrm{ml})$. The mixture was stirred at $\mathrm{rt}$ for $2 \mathrm{~h}$, concentrated, and purified by flash column chromatography (1:9 to $1: 4$ EtOAc-hexane) to yield tricyclic lactam 16a as a mixture of C-6 epimers (ratio 2:1, $16 \mathrm{mg}, 80 \%$ yield). 16a (major): IR ( NaCl) 1659, $1734 \mathrm{~cm}^{-1} ;{ }^{1} \mathrm{H}$ NMR (400 $\left.\mathrm{MHz}, \mathrm{CDCl}_{3}, \mathrm{HETCOR}\right) \delta 2.30-2.45\left(\mathrm{~m}, 3 \mathrm{H}, 2 \mathrm{H}-10, \mathrm{CH}_{2}\right)$, $2.35\left(\mathrm{dd}, J=12.0,4.0 \mathrm{~Hz}, 1 \mathrm{H}, \mathrm{CH}_{2}\right), 3.24(\mathrm{~d}, J=4.0 \mathrm{~Hz}, 1 \mathrm{H}$, H-7), 3.67 (d, $J=6.4 \mathrm{~Hz}, 1 \mathrm{H}, \mathrm{H}-6), 4.00$ (t, $J=8.8 \mathrm{~Hz}, 1 \mathrm{H}, \mathrm{H}-$ 2), 4.61 (t, $J=8.4 \mathrm{~Hz}, 1 \mathrm{H}, \mathrm{H}-2), 5.18$ (d, $J=12.4 \mathrm{~Hz}, 1 \mathrm{H}$, $\mathrm{CH}_{2}$ benzyl), 5.22 (d, $J=12.4 \mathrm{~Hz}, 1 \mathrm{H}, \mathrm{CH}_{2}$ benzyl), 5.48 (t, $J$ $=8.0 \mathrm{~Hz}, 1 \mathrm{H}, \mathrm{H}-3), 5.64(\mathrm{~m}, 1 \mathrm{H}, \mathrm{CH}=), 5.76(\mathrm{~m}, 1 \mathrm{H}, \mathrm{CH}=)$, 7.05-7.20 (m, 10H, ArH); ${ }^{13} \mathrm{C}$ NMR (100.6 MHz, $\left.\mathrm{CDCl}_{3}\right) \delta$ 31.8 (C-10), 34.4 (C-7), $36.1\left(\mathrm{CH}_{2}\right), 52.0(\mathrm{C}-6), 58.7$ (C-3), $67.2\left(\mathrm{CH}_{2}\right.$ benzyl), 70.1 (C-2), 92.3 (C-11), 125.0-129.9 (C-o, $m, p, \mathrm{CH}=), 135.4,139.2$ (C-i), 164.2 (NCO), 169.7 (COO). 16a (minor): ${ }^{1} \mathrm{H}$ NMR (400 MHz, $\mathrm{CDCl}_{3}$, selected resonances) $\delta 2.19$ (ddd, $J=12.4,4.4,1.6 \mathrm{~Hz}, 1 \mathrm{H}, \mathrm{H}-10), 3.05$ (br, $1 \mathrm{H}, \mathrm{H}-$ 7), 3.53 (s, 1H, H-6), 4.02 (dd, $J=9.2,7.6 \mathrm{~Hz}, 1 \mathrm{H}, \mathrm{H}-2), 4.57$ (t, $J=8.8 \mathrm{~Hz}, 1 \mathrm{H}, \mathrm{H}-2), 5.45$ (t, $J=7.6 \mathrm{~Hz}, 1 \mathrm{H}, \mathrm{H}-3), 5.76$ 
$(\mathrm{m}, 1 \mathrm{H}, \mathrm{CH}=), 5.90(\mathrm{~m}, 1 \mathrm{H}, \mathrm{CH}=) ;{ }^{13} \mathrm{C} \mathrm{NMR}(100.6 \mathrm{MHz}$, $\mathrm{CDCl}_{3}$, selected resonances) $\delta 30.9(\mathrm{C}-10), 33.3$ (C-7), 36.2 $\left(\mathrm{CH}_{2}\right), 53.5(\mathrm{C}-6), 57.9(\mathrm{C}-3), 67.0\left(\mathrm{CH}_{2}\right.$ benzyl), $70.1(\mathrm{C}-2)$, 92.4 (C-11), 164.5 (NCO), 168.9 (COO); HMRS calcd for $\left[\mathrm{C}_{24} \mathrm{H}_{23} \mathrm{NO}_{4}+\mathrm{H}\right]: 390.1699$, found: 390.1704 .

Acknowledgment Financial support from the Ministry of Science and Technology (Spain)-FEDER (project CTQ2006-02390/BQU) and the DURSI, Generalitat de Catalunya (Grant 2005-SGR-0603) is gratefully acknowledged. Thanks are also due to the Ministry of Science and Technology (Spain) for a fellowship to A.T.M. and Dr. Daniele Passarella, University degli Studi di Milano, for helpful collaboration.

Supporting Information Available: Experimental procedures and full spectroscopic data for all compounds, and copies of ${ }^{1} \mathrm{H}$ and ${ }^{13} \mathrm{C}$ NMR spectra of all new compounds. This material is available free of change via the Internet at http://pubs.acs.org.

\section{References}

${ }^{1}$ For reviews, see: (a) Romo, D.; Meyers, A. I. Tetrahedron 1991, 47, 9503-9569. (b) Meyers, A. I.; Brengel, G. P. Chem. Commun. 1997, 1-8. (c) Groaning, M. D.; Meyers, A. I. Tetrahedron 2000, 56, 9843-9873. (d) Escolano, C.; Amat, M.; Bosch, J. Chem. Eur. J. 2006, 12, 8198-8207. For more recent work, see: e) Amat, M.; Santos, M. M. M.; Gómez, A. M.; Jokic, D.; Molins, E.; Bosch, J. Org. Lett. 2007, 9, 2907-2910. f) Allin, S. M.; Duffy, L. J.; Page, P. C. B.; Mckee, V.; McKenzie, M. J. Tetrahedron Lett. 2007, 48, 4711-4714. g) Amat, M.; Griera, R.; Fabregat, R.; Molins, E.; Bosch, J. Angew. Chem. Int. Ed. 2008, 47, 3348-3351.

${ }^{2}$ For recent reviews on the synthesis of piperidines, see: (a) Laschat, S.; Dickner, T. Synthesis 2000, 13, 1781-1813. (b) Weintraub, P. M.; Sabol, J. S.; Kane, J. M.; Borcherding, D. R. Tetrahedron, 2003, 59, 2953-2989. (c) Buffat, M. G. P. Tetrahedron, 2004, 60, 1701-1729. For a recent review on the synthesis of pharmaceutically active compounds containing a disubstituted piperidine framework, see: (d) Källström, S.; Leino, R. Bioorg. Med. Chem. 2008, 16, 601-635.

${ }^{3}$ Amat, M.; Bosch, J.; Hidalgo, J.; Cantó, M.; Pérez, M.; Llor, N.; Molins, E.; Miravitlles, C.; Orozco, M.; Luque, J. J. Org. Chem. 2000, 65, 3074-3084.

${ }^{4}$ Amat, M.; Pérez, M.; Minaglia, A. T.; Peretto, B.; Bosch, J. Tetrahedron 2007, 63, 5839-5848.

5 Amat, M.; Pérez, M.; Llor, N.; Escolano, C.; Luque, F. J.; Molins, E.; Bosch, J. J. Org. Chem. 2004, 69, 8681-8693.

${ }^{6}$ (a) Amat, M.; Pérez, M.; Llor, N.; Bosch, J.; Lago, E.; Molins, E. Org. Lett. 2001, 3, 611-614. (b) Amat, M.; Pérez, M.; Llor, N.; Bosch, J. Org. Lett. 2002, 4, 2787-2790. See also references 3 and 5 .

7 (a) Deslongchamps, P. Stereoelectronic Effects in Organic Chemistry; Pergamon Press: Oxford, 1983, p 221. (b) Perlmutter, P. Conjugate Addition Reactions in Organic Synthesis; Pergamon Press: Oxford, 1992, p 25.

${ }^{8}$ For recent related examples, see: (a) Brewster, A. G.; Broady, S.; Hughes, M.; Moloney, M. G.; Woods, G. A. Org. Biomol. Chem. 2004, 2, 1800-1810. (b) Allin, S. M.; Khera, J. S.; Thomas, C. I.; Witherington, J.; Doyle, K.; Elsegood, M. R. J.; Edgar, M. Tetrahedron Lett. 2006, 47, 1961-1964.
9 (a) Muller, M.; Schoenfelder, A.; Didier, B.; Mann, A.; Wermuth, C.-G. Chem. Commun. 1999, 683-684. (b) Hanessian, S.; van Otterlo, W. A. L.; Nilsson, I.; Bauer, U. Tetrahedron Lett. 2002, 43, 1995-1998. (c) García, E.; Lete, E.; Sotomayor, N. J. Org. Chem. 2006, 71, 6776-6784.

${ }^{10}$ Unsaturated lactams $\mathbf{3}$ and $\mathbf{1 4}$ are acid and base sensitive and must be prepared immediately before the next reaction and used without further purification.

11 The starting lactams $\mathbf{1 a}$ and $\mathbf{1 b}$ were prepared by cyclocondensation of $(R)$-phenylglycinol with 5-oxohexanoic acid $^{11 \mathrm{a}}$ and 5-oxo-6-phenylpentanoic acid, ${ }^{1 \mathrm{~b}}$ respectively. (a) Munchhof, M. J.; Meyers, A. I. J. Org. Chem. 1995, 60, 70847085. (b) Amat, M.; Bassas, O.; Llor, N.; Cantó, M.; Pérez, M.; Molins, E.; Bosch, J. Chem. Eur. J. 2006, 12, 7872-7881.

12 (a) Overman, L. E.; Robichaud, A. J. J. Am. Chem. Soc. 1989, 111, 300-308. (b) Amat, M.; Llor, N.; Bosch, J.; Solans, X. Tetrahedron 1997, 53, 719-730. (c) Cossy, J.; Mirguet, O.; Gomez Pardo, D.; Desmurs, J.-R. New J. Chem. 2003, 27, 475482. (d) Deiters, A.; Pettersson, M.; Martin, S. F. J. Org. Chem. 2006, 71, 6547-6561 and references cited therein.

13 (a) Corey, E. J.; Boaz, N. W. Tetrahedron Lett. 1985, 26, 6019-6022. (b) Alexakis, A.; Berlan, J.; Besace, Y. Tetrahedron Lett. 1986, 27, 1047-1050. (c) Nakamura, E.; Matsuzawa, S.; Horiguchi, Y.; Kuwajima, I. Tetrahedron Lett. 1986, 27, 40294032 .

14 For a discussion on the stereochemical outcome in the reduction of 8a-substituted oxazolopiperidone lactams, see reference $11 \mathrm{~b}$ and references cited therein.

${ }^{15}$ Lactam 12a was prepared in three steps $\left(1 . \mathrm{H}_{2}, \mathrm{Pd} / \mathrm{C} ; 2 . n\right.$ $\mathrm{Bu}_{3} \mathrm{P}, o-\mathrm{NO}_{2}\left(\mathrm{C}_{6} \mathrm{H}_{4}\right) \mathrm{SeCN}$; 3. $\mathrm{H}_{2} \mathrm{O}_{2}$, Pyr.; $40 \%$ overall yield) from the known ${ }^{11 a} 8$ a-benzyloxypropyl substituted lactam.

16 (a) Lactam 12b was prepared in 57\% yield by cyclocondensation of $(R)$-phenylglycinol with the known ${ }^{16 \mathrm{~b}} 5$ oxo-8-nonenoic acid. (b) Mazur, P.; Nakanishi, K. J. Org. Chem. 1992, 57, 1047-1051.

${ }^{17}$ (a) Handbook of Metathesis; Grubbs, R. H., Ed; Wiley-VCH: Weinheim, 2003; volumes 1-3. (b) Felpin, F.-X.; Lebreton, J. Eur. J. Org. Chem. 2003, 3693-3712.(c) Deiters, A.; Martin, S. F. Chem. Rev. 2004, 104, 2199-2238.

18 To our knowlewdge this is the first synthetic route to enantiopure 7-azabicyclo[4.3.1]decanes.

19 The synthesis of enantiopure 2-azabicyclo[3.3.1]nonanes has been little explored: (a) Quirante, J.; Torra, M.; Diaba, F.; Escolano, C.; Bonjoch, J. Tetrahedron: Asymmetry 1999, 10, 2399-2410. (b) Karig, G.; Fuchs, A.; Büsing, A.; Brandstetter, T.; Scherer, S.; Bats, J. W.; Eschenmoser, A.; Quinkert, G. Helv. Chim. Acta 2000, 83, 1049-1078.

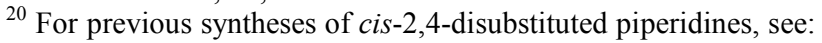
(a) Beak, P.; Lee, W.-K. J. Org. Chem. 1990, 55, 2578-2590. (b) Dwyer, M. P.; Lamar, J. E.; Meyers, A. I. Tetrahedron Lett. 1999, 40, 8965-8968. (c) Watson, P. S.; Jiang, B.; Scott, B. Org. Lett. 2000, 2, 3679-3681. 